\title{
ANALISIS KESALAHAN EJAAN DALAM SITUS DARING KOMPASIANA.COM EDISI JANUARI'FEBRUARI TAHUN 2020 DAN RELEVANSINYA DENGAN PEMBELAJARAN BAHASA INDONESIA DI SMA/MA
}

\author{
ANALYSIS OF SPELLING MISTAKE KOMPASIANA.COM WEBSITE \\ JANUARY"FEBRUARY EDITION 2020 AND ITS RELEVANCE WITH \\ INDONESIAN LANGUAGE LEARNING IN SMA/MA
}

\author{
Miftachaturrohmatil Wachidah ${ }^{1}$, dan Dian Uswatun Hasanah ${ }^{2}$ \\ Program Studi Tadris Bahasa Indonesia, IAIN Surakarta \\ Pos-el: wmita1998@gmail.com
}

\begin{abstract}
This study aimed to describe the form of spelling errors in the January"February 2020 edition of the Kompasiana.com online site and their relevance to Indonesian language learning in $S M A / M A$. In writing articles should be in accordance with the Pedoman Umum Ejaan Bahasa Indonesia (PUEBI). However, the use of spelling has received less attention from mass media article writers. This wrongdoings could lead to misunderstandings and the messages improperly conveyed to the readers. This research is a part of qualitative descriptive study using error analysis work procedures to describe the obtained various errors. The data collection procedure in this study was carried out using the reading and note-taking method. The result shown that article writers' low level of concern in conducted the application of spelling rules. In addition, this research has relevance to Indonesian language learning in $S M A / M A$ is in tune with KD 3.3 and KD 4.3.
\end{abstract}

Keywords: Analysis Spelling Mistake, Kompasiana.com, Indonesian Language Learning.

\begin{abstract}
Abstrak
Penelitian ini bertujuan mendeskripsikan bentuk kesalahan ejaan dalam situs daring Kompasiana.com edisi Januari "Februari tahun 2020 dan relevansinya dengan pembelajaran bahasa Indonesia di SMA/ MA. Penulisan artikel hendaknya sesuai dengan Pedoman Umum Ejaan Ba7hasa Indonesia (PUEBI). Namun, penggunaan ejaan kurang diperhatikan oleh penulis artikel media massa. Hal ini dapat menimbulkan adanya kesalahpahaman dan pesan tidak tersampaikan dengan baik kepada pembaca. Penelitian ini merupakan penelitian deskriptif kualitatif dengan menggunakan prosedur kerja analisis kesalahan untuk mendeskripsikan berbagai kesalahan yang diperoleh. Prosedur pengumpulan data dalam penelitian ini dilakukan dengan metode baca dan catat. Hasil penelitian menunjukkan rendahnya tingkat kepedulian penulis artikel terhadap penerapan kaidah ejaan. Selain itu, relevansi antara penelitian ini dengan pembelajaran bahasa Indonesia di SMA/MA sesuai dengan KD 3.3 dan KD 4.3.
\end{abstract}

Kata-kata Kunci: Analisis Kesalahan Ejaan, Kompasiana.com, Pembelajaran Bahasa Indonesia. 


\section{PENDAHULUAN}

Bahasa berperan penting dalam proses interaksi sosial di masyarakat. Bahasa yang dimaksud adalah bahasa tulis dan bahasa lisan. Bahasa tulis berwujud tulisan, sedangkan bahasa lisan merupakan ujaran secara langsung. Bahasa merupakan sebuah alat komunikasi verbal berupa tuturan yang diciptakan oleh alat ucap manusia atau tulisan sebagai bentuk representasi dari ujaran tersebut (Wijana, 2011:1). Hal ini relevan dengan pendapat Saddhono (dalam Rosita and Achsani, 2018:21), bahwa salah satu alat yang dipakai dalam proses komunikasi adalah bahasa. Manusia memanfaatkan bahasa sebagai perantara untuk menyampaikan pendapat dan informasi.

Salah satu penyedia informasi adalah media massa. Menurut Yunus (2010:27), media massa ialah sebuah jenis sarana komunikasi untuk meneruskan atau mengumumkan informasi kepada khalayak. Keberadaan media massa di Indonesia mengalami kemajuan yang cukup pesat. Media massa bukan hanya berbentuk media cetak dan media elektronik, tetapi juga terdapat media online atau daring (dalam jaringan). Kini, masyarakat dapat memperoleh informasi dari berbagai daerah di Indonesia, bahkan seluruh dunia melalui media cetak, elektronik, maupun daring.

Media daring merupakan media yang populer dan diminati di masa sekarang ini. Apabila dipadankan dengan media cetak dan elektronik, media ini lebih mudah diakses di berbagai tempat dan waktu dengan memanfaatkan adanya koneksi internet. Tamburaka (2013:75) berpendapat bahwa internet adalah sebuah jaringan yang dapat mengaitkan komputer-komputer di dunia dan mendirikan kelompok dunia maya yang disebut dengan global village (desa global). Kehadiran internet memberi manfaat kepada manusia untuk dapat mengakses informasi yang dibutuhkan dari belahan dunia. Salah satu media informasi yang dapat diakses dari internet, yaitu blog.
Blog merupakan situs daring yang berisi mengenai berbagai catatan atau informasi yang bebas diakses oleh siapa saja dengan internet. Penggunaan media daring ini memiliki kelebihan, yakni mendapatkan informasi secara cepat mengenai berbagai bidang. Dengan adanya jaringan internet, masyarakat dapat mengakses informasi dari seluruh dunia secara efisien.

Bahasa yang dipakai media massa disebut dengan bahasa jurnalistik. Menurut Anwar (dalam Fathan, 2014:2), bahasa jurnalistik adalah sebuah bahasa yang dipakai oleh pewarta untuk menulis karya-karya jurnalistik di media massa. Penggunaan bahasa dalam penulisan informasi di media massa, hendaknya menggunakan bahasa baku. Hal ini relevan dengan pendapat Anton M. Moeliono (dalam Sarwoko, 2007:1) yang mengemukakan bahwa bahasa jurnalistik termasuk ke dalam ragam bahasa baku. Akan tetapi, dalam praktiknya, penulisan informasi di media massa tidak selalu Kadera Bahasa, Volume 12 Nomor 2, Edisi Agustus 2020 tunduk kepada kaidah kebahasaan atau bahasa baku. Salah satu media tersebut adalah situs daring Kompasiana.com.

Berdasarkan informasi yang diperoleh dari situs Kompasiana.com (2018), situs Kompasiana.com merupakan laman blog dan publikasi daring yang didirikan oleh Kompas Cyber Media sejak 22 Oktober 2008. Pada tahun pertama didirikan, situs ini hanya laman blog yang diperuntukkan bagi jurnalis dan karyawan Kompas Gramedia saja. Kemudian, pada tahun kedua, situs ini berubah menjadi laman blog untuk semua orang. Laman ini merupakan media saluran berita dan opini masyarakat (Citizen News and Opinion Channel). Pengguna internet dapat menulis pada laman ini apabila telah memiliki akun kompasiana. Penulis artikel dalam situs ini disebut dengan kompasianer.

Bahasa yang digunakan dalam penulisan di media massa hendaklah sesuai dengan kaidah kebahasaan yang berlaku. Terlebih, situs daring 
Kompasiana.com terdapat beragam informasi dari berbagai bidang sesuai dengan kolom-kolom tertentu. Selain itu, situs ini memiliki banyak penggemarnya. Apabila penulis artikel tidak memperhatikan kaidah kebahasaan, maka memungkinkan pembaca dapat mencontoh kesalahan penggunaan bahasa tersebut.

Kesalahan penggunaan bahasa melanggar faktor penentu dalam berkomunikasi. Oleh karena itu, proses komunikasi tidak akan berjalan lancar, serta pesan tidak dapat dipahami dengan baik oleh pembaca. Hal ini sependapat dengan Wachidah, dkk. (2019:2), yang mengemukakan bahwa kesalahan berbahasa dapat mengakibatkan kesalahpahaman dan kendala pada proses komunikasi, yang termasuk kesalahan berbahasa adalah kesalahan dalam bidang ejaan, diksi atau leksikal, tanda baca, pemilihan kata dan sebagainya. Kesalahan berbahasa timbul karena ketidakpatuhan pengguna bahasa terhadap kaidah bahasa.

Ejaan bahasa berperan penting dalam penulisan informasi di media massa. Berdasarkan Peraturan Menteri Pendidikan dan Kebudayaan Republik Indonesia Nomor 50 tahun 2015 tentang Pedoman Umum Ejaan Bahasa Indonesia (PUEBI) diberlakukan sebagai petunjuk atau rujukan dan kaidah bahasa. Kesalahan ejaan sering dijumpai pada situs daring Kompasiana.com. Nasucha, dkk. (Inderasari and Agustina, 2017:8) mengemukakan bahwa pada realitanya, penggunaan bahasa masih banyak ditemukan adanya kesalahan berbahasa yang terjadi lantaran kesalahan dalam mempraktikkan penggunaan ejaan, seperti tanda baca. Kesalahan ejaan terjadi karena minimnya kepedulian penulis dalam mempraktikkan kaidah ejaan.

Peneliti tertarik untuk meneliti kesalahan berbahasa dalam situs daring Kompasiana.com. Hal yang menarik terletak pada seberapa tingkat kepedulian penulis artikel atau disebut kompasianer terhadap kaidah bahasa Indonesia, seperti ejaan. Situs ini merupakan situs saluran berita dan opini masyarakat yang memiliki banyak pengunjung, yaitu 13 juta per bulan. Pada tahun 2017, situs ini masuk peringkat sepuluh besar sebagai media digital di Indonesia versi ComScore. Oleh sebab itu, hendaknya dalam penulisan informasi atau berita memperhatikan kaidah kebahasaan, demi menghindari kesalahpahaman penafsiran makna oleh pembaca.

Salah satu mata pelajaran yang harus ada di segala tingkat pendidikan yaitu mata pelajaran bahasa Indonesia. Pembelajaran ini dapat mengasah keterampilan berbahasa siswa, baik lisan maupun tulisan. Metode pembelajaran pada Kurikulum 2013 dituntut untuk menerapkan ranah sikap, pengetahuan dan keterampilan. Terdapat empat aspek keterampilan berbahasa yang tercakup dalam pengajaran bahasa, yaitu keterampilan menyimak, membaca, berbicara dan menulis.

Penelitian ini relevan dengan Kurikulum 2013 pada mata pelajaran bahasa Indonesia di SMA/ MA kelas X untuk KD 3.3, yakni menganalisis struktur, isi (permasalahan, argumentasi, pengetahuan, dan rekomendasi), kebahasaan teks eksposisi yang didengar dan atau dibaca, dan KD 4.3, yakni mengembangkan isi (permasalahan, argumen, pengetahuan, dan rekomendasi) teks eksposisi secara lisan dan tulis. Berdasarkan KD tersebut, dipaparkan bahwa dalam menulis teks eksposisi, hendaknya berlandaskan pada struktur, isi, dan kebahasaan.

Berdasarkan paparan di atas, peneliti memutuskan untuk memberi judul, "Analisis Kesalahan Ejaan dalam Situs Daring Kompasiana.com Edisi Januari"Februari Tahun 2020 dan Relevansinya dengan Pembelajaran Bahasa Indonesia di SMA/MA.” Penelitian ini dilaksanakan dengan maksud mendeskripsikan bentuk kesalahan ejaan dan relevansinya dengan pembelajaran bahasa Indonesia di SMA/MA.

Penelitian ini relevan dengan penelitian yang dilakukan oleh Diana Murni dalam Jurnal Bahasa, 
Sastra, dan Pembelajarannya edisi volume 7 (2) tabun 2017, dengan judul "Analisis Kesalahan Penggunaan Kalimat Bahasa Indonesia dalam Penulisan Tajuk di Surat Kabar Banjarmasin Post (The Error Analysis of The Using of Indonesian Language Kadera Bahasa, Volume 12 Nomor 2, Edisi Agustus 2020

Sentences in The Writing of Editorials on Banjarmasin Post Newspaper)." Penelitian ini mempunyai kesamaan dengan penelitian yang dilakukan oleh Diana Murni, yakni sama-sama menggunakan metode kualitatif. Adapun perbedaan kedua penelitian ini yakni terdapat pada fokus penelitian. Penelitian ini fokus pada kesalahan ejaan, sedangkan penelitian Diana Murni hanya fokus pada kalimat. Selain itu, objek penelitian ini mengenai situs daring Kompasiana.com, sedangkan objek penelitian Diana Murni, yaitu penulisan tajuk di surat kabar Banjarmasin Post.

\section{LANDASAN TEORI}

\section{Kesalahan Berbahasa}

Kesalahan berbahasa merupakan pemakaian bahasa lisan maupun tulis yang melanggar faktorfaktor penentu komunikasi, asas kemasyarakatan, dan pedoman tata bahasa Indonesia (Setyawati, 2010:13). Kesalahan berbahasa adalah pelanggaran kaidah tata bahasa Indonesia dalam penggunaan bahasa lisan maupun tulis.

Kesalahan berbahasa disebabkan oleh rendahnya pemahaman seseorang mengenai aspek kebahasaan. Menurut Setyawati (2010:15), terdapat tiga kemungkinan seseorang mengalami kesalahan dalam berbahasa, yaitu terpengaruh oleh bahasa yang dikuasainya lebih dahulu, ketidakpahaman pengguna bahasa mengenai bahasa yang digunakannya, dan tidak tepat dan sempurnanya pengajaran bahasa.

Analisis kesalahan berbahasa adalah sebuah tahap untuk mengenali, mengelompokkan, dan menafsirkan secara sistematis mengenai kesalahan yang diperbuat oleh peserta didik dalam pembelajaran B2 (bahasa asing) dengan memakai teori dan prosedur yang berkaitan dengan kebahasaan (Crystal dalam Gantamitreka dan Shokha, 2016:201).

\section{Kesalahan Ejaan}

Kesalahan ejaan tergolong bentuk kesalahan berbahasa dalam bahasa tulis yang dapat memengaruhi sebuah tulisan (Wijayanti, 2016: 186). Sebuah tulisan tidak hanya dianggap baik dari segi isinya, tetapi juga dapat dilihat dari penggunaan ejaan, seperti tanda baca, penulisan kata, dan sebagainya. Apabila dalam tulisan tersebut tidak memperhatikan kaidah ejaan, maka isi tulisan tersebut tidak tersampaikan dengan baik kepada pembaca.

Penggunaan ejaan dalam sebuah tulisan harus benar-benar diperhatikan. Apabila pengguna bahasa lalai, maka tulisan tersebut akan sukar dipahami. Setyawati (Afiana, 2018:72) mengemukakan bahwa kesalahan ejaan tidak sekadar berhubungan dengan cara mengeja suatu kata, tetapi lebih berhubungan dengan upaya menata penulisan huruf agar membentuk satuan yang lebih besar, seperti kata, kelompok kata, dan kalimat.

Menulis artikel di media massa hendaknya patuh terhadap kaidah ejaan. Kaidah ejaan yang berlaku saat ini, yaitu Pedoman Umum Ejaan Bahasa Indonesia (PUEBI) edisi keempat. Pedoman ini berlandaskan pada Peraturan Menteri Pendidikan dan Kebudayaan Republik Indonesia Nomor 50 Tahun 2015. Pedoman tersebut terdiri dari 35 pembahasan, yaitu pemakaian huruf abjad, vokal, konsonan, diftong, gabungan huruf konsonan, kapital, miring, dan tebal; penulisan kata dasar, berimbuhan, bentuk ulang, gabungan kata, pemenggalan kata, kata depan, partikel, singkatan dan akronim, angka dan bilangan, kata ganti ku-, kau-, -ku, - 
Analisis Kesalahan Ejaan Dalam Situs Daring Kompasiana.com Edisi Januari-Februari Tahun 2020 dan Relevansinya ...

mu, dan-nya, kata sandang si dan sang; pemakaian tanda baca titik, koma, titik koma, titik dua, hubung, pisah, seru, elipisis, petik, petik tunggal, kurung, kurung siku, garis miring, penyingkat atau apostrof; dan penulisan unsur serapan.

\section{METODE PENELITIAN}

Jenis penelitian ini adalah studi pustaka, dengan memakai metode penelitian deskriptif kualitatif. Menurut Bogdan dan Taylor (Muhammad, 2014:30), metode kualitatif adalah langkah penelitian yang memunculkan data deskriptif berbentuk kata-kata mengenai seseorang dan perbuatan yang sedang diamati atau dilihat. Penelitian ini memunculkan data deskriptif berbentuk kata-kata mengenai hal-hal yang diteliti.

Penelitian ini memiliki sumber data berupa dokumen. Dokumen ini berbentuk artikel dalam situs daring Kompasiana.com edisi Januari"Februari 2020 dan silabus bahasa Indonesia edisi revisi 2019. Peneliti mengambil 14 sampel dari artikel edisi Januari dan Februari diambil secara acak, masing-masing sejumlah 7 artikel.

Teknik yang dipakai untuk menemukan kesalahan ejaan pada situs daring Kompasiana.com, yaitu dengan menggunakan teknik baca dan catat. Teknik ini dipandang paling serasi dengan sumber data, yaitu berupa tulisan di situs daring Kompasiana.com. Teknik baca yang dilakukan, yaitu dengan membaca secara keseluruhan sampel artikel yang diteliti. Adapun teknik catat yaitu metode yang digunakan dalam menemukan data dengan cara menyalin hasil kesalahan yang diperoleh dari kegiatan menyimak atau membaca.

Penelitian ini menggunakan teori triangulasi dalam memeriksa keabsahan data. Afifuddin dan Saebani (2012:144) Kadera Bahasa, Volume 12 Nomor 2, Edisi Agustus 2020

mengungkapkan bahwa teori triangulasi merupakan pemakaian beragam teori dalam pene- litian yang berlainan dengan tujuan untuk menentukan bahwa data yang telah dihimpun melengkapi syarat. Hal itu dilakukan dengan tujuan menyelidiki persoalan yang sedang dikaji agar dapat ditarik kesimpulan yang dapat dipertanggungjawabkan kebenaran dan keabsahannya.

Penelitian ini berfokus pada analisis kesalahan ejaan dalam situs daring Kompasiana.com edisi Januari"Februari tahun 2020 dan implikasinya dengan pembelajaran bahasa Indonesia di SMA/ MA. Oleh karena itu, peneliti menerapkan prosedur kerja analisis kesalahan yang sesuai dengan tema penelitian. Ellis (dalam Tarigan dan Djago Tarigan, 2011:61) mengemukakan bahwa ada lima prosedur kerja analisis kesalahan, yaitu pengumpulan sampel kesalahan, identifikasi kesalahan pada sampel, penguraian kesalahan, penggolongan kesalahan berdasarkan penyebab, dan pengevaluasian tingkat kesalahan.

Pembahasan dalam penelitian ini berbentuk kesalahan ejaan dalam situs daring Kompasiana.com edisi Januari-Februari tahun 2020 dan relevansinya dengan pembelajaran bahasa Indonesia di SMA/ MA didasarkan pada hasil analisis. Pembahasan pada penelitian ini dilakukan dengan cara mendeskripsikan sampel kesalahan yang ditemukan dalam data. Selain itu, peneliti juga menyertakan pembetulan dari kesalahan tersebut. Pada penelitian ini, peneliti mengambil sampel kesalahan yang mewakili untuk dideskripsikan. Hal ini dilakukan karena data kesalahan yang ditemukan cukup banyak.

\section{PEMBAHASAN}

Kesalahan Ejaan dalam Situs Daring Kompasiana.com Edisi Januari'Februari Tahun 2020

(1) Berau, lewat danau Kakaban yang terletak di pulau Kakaban, kepulauan Derawan merupakan rumah bagi ubur-ubur tidak menyengat... (D01) 
Kalimat (1) menunjukkan kesalahan pemakaian huruf kapital pada unsur nama geografi. Kutipan danau Kakaban, pulau Kakaban dan kepulauan Derawan, merupakan unsur nama geografi yang huruf awal katanya tidak ditulis dengan huruf kapital. Seharusnya, huruf awal kata ditulis dengan huruf kapital, karena merupakan unsur nama geografi. Kalimat tersebut dapat diperbaiki menjadi: Berau, lewat Danau Kakaban yang terletak di Pulau Kakaban, Kepulauan Derawan, merupakan rumah bagi ubur-ubur tidak menyengat... .

(2) Tanpa bahasa seorang bayi akan sulit mengutarakan rasa lapar, haus, dan lainnya. (A04) Kalimat pada data (2) menunjukkan adanya kesalahan penggunaan tanda koma. Pada kalimat tersebut, antara kata Tanpa bahasa sebagai anak kalimat dan kalimat seorang bayi... sebagai induk kalimat tidak disertai tanda koma. Seharusnya, di antara kata bahasa dan seorang tersebut disertai dengan tanda koma, untuk memisahkan anak kalimat yang mengawali induk kalimatnya. Oleh karena itu, kalimat tersebut dinyatakan salah. Pembetulan kalimat tersebut sebagai berikut: Tanpa bahasa, seorang bayi akan sulit mengutarakan rasa lapar, haus, dan lainnya.

(3) Saya sendiripun kerap mengalami situasi semacam itu. (F14)

Kalimat (3) menunjukkan kesalahan penulisan partikel pun. Partikel pun ditulis secara terpisah dengan kata yang mengawalinya. Kata sendiripun dalam kalimat tersebut ditulis secara serangkai. seharusnya, kata sendiripun ditulis terpisah menjadi sendiri pun. Hal ini, dilakukan karena kata tersebut bukan merupakan kata penghubung yang harus ditulis serangkai. Kalimat tersebut dapat diperbaiki menjadi: Saya sendiri pun kerap mengalami situasi semacam itu.

(4) ...tetapi ada orang yang mengatakan "ngapain dulu kuliah kalau akhirnya jualan?” (F01)
Kalimat (4) menunjukkan kesalahan dalam pemakaian tanda baca koma dan huruf kapital. Antara kata mengatakan dan petikan langsung dalam kalimat tersebut, tidak disertai dengan tanda koma. Seharusnya, antara kata mengatakan dan petikan langsung disertai dengan tanda koma. Hal ini, bertujuan untuk memisahkan antara petikan langsung dengan bagian lain dalam kalimat. Huruf pertama pada petikan langsung ngapain ditulis dengan huruf kecil. Seharusnya, penulisan huruf pertama petikan langsung ngapain dengan huruf kapital. Hal ini, dilakukan sebab kata tersebut merupakan awal kalimat dalam petikan langsung. Kalimat tersebut dapat diperbaiki menjadi: ...tetapi ada orang yang mengatakan, "Ngapain dulu kuliah kalau akhirnya jualan?”

(5) Masalah masalah yang seharusnya sudah usai dibincangkan beberapa puluh tahun lalu, dibincangkan lagi seperti soal perbedaan keyakinan, etnis dan sebagainya. (B13)

Kalimat (5) menunjukkan kesalahan dalam pemakaian tanda hubung dan penulisan bentuk ulang. Antara kata masalah masalah tidak disertai dengan tanda hubung. Padahal, kata tersebut merupakan bentuk ulang. Seharusnya, antara kata tersebut disertai dengan tanda hubung menjadi masalah-masalah. Hal tersebut dilakukan karena kata tersebut termasuk bentuk kata ulang. Kalimat tersebut dapat diperbaiki menjadi: Masalah-masalah yang seharusnya sudah Kadera Bahasa, Volume 12 Nomor 2, Edisi Agustus 2020 usai dibincangkan beberapa puluh tahun lalu, dibincangkan lagi seperti soal perbedaan keyakinan, etnis, dan sebagainya.

(6) ...atau transfer ke Bank Syariah Mandiri (451) 7777274xxx a.n Kurir Langit. (J05)

Kalimat (6) menunjukkan kesalahan dalam penulisan singkatan dan akronim. Setelah huruf $n$ pada singkatan a.n tidak disertai dengan tanda baca titik. Singkatan yang meliputi dua huruf, 
Analisis Kesalahan Ejaan Dalam Situs Daring Kompasiana.com Edisi Januari-Februari Tahun 2020 dan Relevansinya ...

masing-masing disertai dengan tanda titik. Oleh karena itu, seharusnya setelah huruf $n$ disertai dengan tanda titik. Kalimat tersebut dapat diperbaiki menjadi: ...atau transfer ke Bank Syariah Mandiri (451) 7777274xxx a.n. Kurir Langit.

(7) Mereka butuh makanan, peralatan dapur, perlengkapan sholat, perlengkapan mandi agar tetap bisa bersuci, keperluan lansia dan bayi. (J01)

Kalimat (7) menunjukkan kesalahan dalam penulisan unsur serapan. Kata sholat berasal dari bahasa Arab yang diserap ke dalam bahasa Indonesia. Mayoritas masyarakat, dalam hal penulisan dan pelafalan kata tersebut masih menirukan bahasa asing. Padahal, kata sholat sudah diserap menjadi salat dalam kaidah bahasa Indonesia. Kalimat tersebut dapat diperbaiki menjadi: Mereka butuh makanan, peralatan dapur, perlengkapan salat, perlengkapan mandi agar tetap bisa bersuci, dan keperluan lansia dan bayi.

(8) Mr Kobayashi te dan sekolah bernama Tomoe telah lama hancur di luluh lantakkan bom. (N12)

Kalimat (8) menunjukkan adanya kesalahan dalam penulisan singkatan dan akronim serta penulisan gabungan kata. Singkatan $M r$ pada kalimat tersebut tidak disertai tanda baca titik. Seharusnya, di belakang singkatan tersebut diikuti dengan tanda titik. Hal ini dilakukan karena singkatan nama orang, sapaan dan sebagainya disertai dengan tanda titik di setiap unsur singkatan tersebut. Kesalahan penulisan gabungan kata yang mendapat imbuhan di-/-an pada kata di luluh lantakkan, yang tidak ditulis secara serangkai. Penulisan kata tersebut, sebaiknya ditulis serangkai menjadi dilulublantakkan, karena merupakan gabungan kata yang mendapat awalan dan akhiran sekaligus. Kalimat tersebut dapat diperbaiki menjadi: Mr. Kobayashi te dan sekolah bernama Tomoe telah lama hancur diluluhlantakkan bom.
(9) ...acara ini di isi dengan berbagai macam perlombaan, diantaranya adalah lomba desain poster ekonomi syariah, prakarya layak jual, dan di akhir acara di tutup dengan seminar. (I06)

Kalimat (9) menunjukkan kesalahan penulisan kata depan di dan tanda titik di akhir kalimat. Kata depan di pada kata isi dan tutup ditulis secara terpisah. Seharusnya, kata depan tersebut ditulis secara serangkai, karena kata yang menyertainya bukan merupakan unsur yang menunjukkan latar atau tempat. Sebaliknya, kata depan di pada kata diantaranya yang semestinya ditulis terpisah, ditulis secara serangkai. Padahal, kata yang menyertainya tersebut menunjukkan unsur tempat. Setelah kata seminar, diikuti dengan tanda baca koma. Seharusnya, tanda baca koma dirubah dengan tanda baca titik, karena merupakan akhir dari kalimat pernyataan. Kalimat tersebut dapat diperbaiki menjadi: ...acara ini diisi dengan berbagai macam perlombaan, di antaranya adalah lomba desain poster ekonomi syariah, prakarya layak jual, dan di akhir acara ditutup dengan seminar.

(10) Seiring berkembang nya teknologi, game online pun bisa dimainkan menggunakan Komputer, HP, game console. (L02)

Kalimat (10) mengandung kesalahan penulisan kata ganti -nya, huruf miring, partikel, tanda hubung dan huruf kapital. Kata ganti -nya pada kata berkembang nya dalam kalimat tersebut tidak ditulis serangkai. Seharusnya, kata -nya ditulis serangkai dengan kata yang mengawalinya. Kata game online dan game console merupakan istilah asing pada kalimat tersebut yang tidak dicetak miring. Huruf cetak miring berlaku pada penulisan istilah asing atau ungkapan bahasa daerah. Oleh karena itu, sebaiknya istilah tersebut dicetak miring. Kesalahan pemakaian huruf kapital terletak pada huruf pertama Komputer dan HP. Huruf pertama pada kata Komputer dan HP semestinya ditulis 
dengan huruf kecil, karena kedua kata tersebut bukan merupakan huruf pertama pada sebuah kalimat. Penulisan partikel pun pada kata game online pun ditulis tanpa tanda hubung. Game online merupakan istilah asing. Oleh karena itu, di antara unsur bahasa asing dengan bahasa Indonesia tersebut disisipi dengan tanda hubung. Kalimat tersebut dapat diperbaiki menjadi: Seiring berkembangnya teknologi, game online-pun bisa dimainkan menggunakan komputer, hp, game console.

Kesalahan ejaan yang diperoleh pada situs daring Kompasiana.com edisi Januari'"Februari tahun 2020, yaitu 246 kasus. Kesalahan pemakaian huruf ditemukan 91 kasus, yang meliputi: kesalahan penggunaan huruf kapital 49 kasus, dan kesalahan pemakaian huruf miring 42 kasus. Kesalahan penulisan kata sejumlah 36 kasus yang meliputi: kesalahan penulisan bentuk ulang 1 kasus, penulisan gabungan kata 3 kasus, penulisan kata depan 18 kasus, penulisan partikel 5 kasus, singkatan dan akronim 5 kasus, angka dan bilangan 1 kasus, kata ganti ku-, kau-, -ku, -mu, dan -nya 2 kasus, kata sandang si dan Kadera Bahasa, Volume 12 Nomor 2, Edisi Agustus 2020 sang 1 kasus. Kesalahan penggunaan tanda baca sejumlah 116 kesalahan yang meliputi: kesalahan penggunaan tanda titik 5 kasus, tanda baca koma 91 kasus, tanda hubung 12 kasus, tanda tanya 1 kasus, tanda seru 3 kasus, tanda petik 1 kasus, dan tanda petik tunggal 3 kasus. Kesalahan penulisan unsur serapan ditemukan 3 kasus. Kesalahan paling banyak ditemukan pada pemakaian tanda baca koma, yaitu sebanyak 91 kasus. Kesalahan paling sedikit yaitu kesalahan penulisan bentuk ulang, penulisan angka dan bilangan, penulisan kata sandang si dan sang, penggunaan tanda baca tanya dan petik dua yaitu sama-sama ditemukan 1 kasus, sedangkan pemakaian huruf tebal, penulisan kata dasar, kata berimbuhan, pemenggalan kata, pemakaian tanda baca titik koma, tanda titik dua, tanda pisah, tanda elipsis, tanda kurung, tanda kurung siku, tanda garis miring dan tanda penyingkat atau apostrof tidak ditemukan kesalahan.

Berikut adalah tabel frekuensi kesalahan yang ditemukan dalam situs daring Kompasiana.com edisi Januari-Februari tahun 2020.

Tabel Frekuensi Kesalahan Ejaan pada Situs Daring Kompasiana.Com Edisi Januari"Februari Tahun 2020

\begin{tabular}{|c|c|c|}
\hline No & Aspek Kesalahan Ejaan & Frekuensi \\
\hline \multicolumn{3}{|c|}{ Pemakaian Huruf } \\
\hline 1 & Huruf Abjad & - \\
\hline 2 & Huruf Vokal & - \\
\hline 3 & Huruf Konsonan & - \\
\hline 4 & Huruf Diftong & - \\
\hline 5 & $\begin{array}{l}\text { Gabungan Huruf } \\
\text { Konsonan }\end{array}$ & - \\
\hline 6 & Huruf Kapital & 49 \\
\hline 7 & Huruf Miring & 42 \\
\hline 8 & Huruf Tebal & - \\
\hline \multicolumn{3}{|c|}{ Penulisan Kata } \\
\hline 1 & Kata Dasar & - \\
\hline 2 & Kata Berimbuhan & - \\
\hline 3 & Bentuk Ulang & 1 \\
\hline 4 & Gabungan Kata & 3 \\
\hline 5 & Pemenggalan Kata & - \\
\hline 6 & Kata Depan & 18 \\
\hline 7 & Partikel & 5 \\
\hline 8 & Singkatan dan Akronim & 5 \\
\hline 9 & Angka dan Bilangan & 1 \\
\hline 10 & $\begin{array}{l}\text { Kata Ganti ku-, kau-, -ku, - } \\
\text { mu, -nya }\end{array}$ & 2 \\
\hline 11 & Kata Sandang si dan sang & 1 \\
\hline \multicolumn{3}{|c|}{ Pemakaian Tanda Baca } \\
\hline 1 & Tanda Titik (.) & 5 \\
\hline 2 & Tanda Koma (,) & 91 \\
\hline 3 & Tanda Titik Koma (;) & - \\
\hline 4 & Tanda Titik Dua (:) & - \\
\hline 5 & Tanda Hubung (-) & 12 \\
\hline 6 & Tanda Pisah $(-)$ & - \\
\hline 7 & Tanda Tanya (?) & 1 \\
\hline 8 & Tanda Seru (!) & 3 \\
\hline 9 & Tanda Elipsis (...) & - \\
\hline 10 & Tanda Petik (“...”). & 1 \\
\hline 11 & Tanda Petik Tunggal (“...') & 3 \\
\hline 12 & Tanda Kurung $((\ldots))$ & - \\
\hline 13 & Tanda Kurung Siku ([...]) & - \\
\hline 14 & Tanda Garis Miring (/) & - \\
\hline 15 & $\begin{array}{l}\text { Tanda Penyingkat atau } \\
\text { Apostrof }(\mathcal{C}\end{array}$ & - \\
\hline \multicolumn{2}{|r|}{$\frac{1}{\text { Penulisan Unsur Serapan }}$} & 3 \\
\hline & Jumlah & 246 \\
\hline
\end{tabular}


Analisis Kesalahan Ejaan Dalam Situs Daring Kompasiana.com Edisi Januari-Februari Tahun 2020 dan Relevansinya ...

Relevansi Kesalahan Ejaan dengan Pembelajaran Bahasa Indonesia di SMA/MA

Salah satu pembelajaran yang wajib ada di setiap jenjang pendidikan yaitu pembelajaran bahasa Indonesia. Penyusunan materi pembelajaran di sekolah berhubungan dengan kurikulum. Kurikulum membantu guru untuk menentukan materi yang akan diterapkan dalam proses pembelajaran. Apabila telah ditentukan, maka selanjutnya yaitu menyusun alat serta metode yang akan diterapkan dalam pembelajaran. Kurikulum 2013 merupakan kurikulum yang berlaku saat ini. Selain ranah sikap dan pengetahuan, pada kurikulum ini, siswa juga dituntut untuk memiliki keterampilan berbahasa, baik lisan ataupun tulis. Terdapat empat aspek keterampilan dalam berbahasa, yaitu menyimak, membaca, berbicara dan menulis.

Berdasarkan hasil analisis mengenai penelitian kesalahan ejaan pada Kompasiana.com, dapat dikaitkan dengan pembelajaran bahasa Indonesia di SMA/MA. Situs daring ini, berisi beragam artikel yang sesuai dengan tema yang diangkat pada setiap kolom. Adapun relevansi dalam penelitian ini cenderung mempelajari penulisan sesuai dengan Pedoman Umum Ejaan Bahasa Indonesia (PUEBI).

Penelitian ini berkaitan dengan pembelajaran bahasa Indonesia pada kurikulum 2013 di SMA/ MA. Kaitan kesalahan ejaan dalam situs daring Kompasiana.com dengan pembelajaran Kadera Bahasa, Volume 12 Nomor 2, Edisi Agustus 2020

teks eksposisi pada kelas X KD 3.3, yakni menganalisis struktur, isi (permasalahan, argumentasi, pengetahuan, dan rekomendasi), kebahasaan teks eksposisi yang didengar dan atau dibaca, dan KD 4.3, yakni mengembangkan isi (permasalahan, argumen, pengetahuan, dan rekomendasi) teks eksposisi secara lisan dan tulis. Berdasarkan kedua KD tersebut, siswa dituntut dapat menelaah struktur, isi, dan kebahasaan teks eksposisi secara tertulis maupun lisan. Selain itu, siswa juga dituntut dapat menyusun teks eksposisi ber- dasarkan struktur, isi, dan kebahasaannya, serta dapat mempresentasikan hasilnya.

Kompasiana.com berisi mengenai artikel dalam berbagai kolom. Oleh karena itu, penelitian ini sesuai dengan pembelajaran teks eksposisi. Teks eksposisi merupakan sebuah karangan untuk menyampaikan gagasan atau pemikiran mengenai suatu topik. Begitu pun dengan artikel, yang berisi mengenai argumentasi penulis mengenai suatu permasalahan. Oleh karena itu, teks eksposisi yang ditulis siswa hendaknya memperhatikan kaidah ejaan bahasa Indonesia yang berlaku. Penulisan kaidah ejaan yang tepat, dapat meminimalisasi adanya kesalahpahaman dalam memahami isi tulisan. Selain itu, makna yang terkandung dalam sebuah tulisan tidak dapat diterima dengan baik oleh pembaca. Dengan demikian, penting dilakukan pembelajaran mengenai kaidah ejaan bagi siswa.

Hasil analisis kesalahan ejaan pada penelitian ini dapat digunakan sebagai materi pembelajaran teks eksposisi KD 3.3 dan KD 4.3, yakni siswa dituntut dapat memproduksi teks eksposisi. Sebelum memproduksi teks eksposisi, siswa diharapkan dapat menelaah struktur, isi, dan kebahasaan teks eksposisi. pada proses pembelajaran, guru dapat mengambil contoh artikel dalam penelitian ini beserta pembahasannya. Siswa diharapkan dapat menelaah struktur, isi, dan kebahasaan artikel tersebut. Selain itu, siswa juga diharapkan memahami analisis kesalahan ejaan pada artikel tersebut sehingga siswa dapat belajar dari kesalahankesalahan ejaan yang disajikan serta dapat mengaplikasikan pemahamannya pada penulisan artikel atau teks eksposisi. Oleh karena itu, penelitian ini dapat dijadikan referensi atau rujukan dalam pembelajaran bahasa Indonesia, khususnya materi teks eksposisi. 


\section{PENUTUP}

Berdasarkan hasil analisis data dan pembahasan hasil penelitian yang dikaitkan dengan teori yang digunakan, penelitian ini menunjukkan bahwa tingkat kepedulian penulis artikel terhadap kaidah tata bahasa Indonesia, khususnya bidang ejaan masih terbilang rendah. Hal ini dibuktikan dengan ditemukannya berbagai kesalahan pada artikel di situs daring Kompasiana.com. Kesalahankesalahan tersebut di antaranya pemakaian huruf kapital dan huruf miring, penulisan: bentuk ulang, gabungan kata, kata depan, partikel, singkatan dan akronim, angka dan bilangan, kata ganti ku-, kau$-k u$, -mu, dan -nya, kata sandang si dan sang, pemakaian tanda baca: titik, koma, hubung, tanya, seru, petik, petik tunggal, dan penulisan unsur serapan. Kesalahan ejaan yang dominan ditemukan pada setiap sampel artikel, yaitu pemakaian tanda baca koma. Kesalahan ejaan dipengaruhi minimnya kepedulian penulis artikel terhadap penerapan kaidah ejaan dalam penulisan artikel. Selain itu, dipengaruhi oleh rendahnya pemahaman penulis artikel terhadap kaidah ejaan. Penulis artikel di situs daring Kompasiana.com terdiri dari masyarakat secara luas, yang tidak dibatasi oleh umur, pendidikan, agama, dan sebagainya. Jadi, masyarakat secara bebas menulis artikel di situs ini. Oleh karena itu, wajar saja apabila terjadi kesalahan-kesalahan dalam penerapan ejaan.

Penelitian ini relevan dengan pembelajaran bahasa Indonesia di SMA/MA pada teks eksposisi kelas X KD 3.3, yakni menganalisis struktur, isi (permasalahan, argumentasi, pengetahuan, dan rekomendasi), kebahasaan teks eksposisi yang didengar dan atau dibaca, dan KD 4.3, yakni mengembangkan isi (permasalahan, argumen, pengetahuan, dan rekomendasi) teks eksposisi secara lisan dan tulis. Sebelum memproduksi teks eksposisi, siswa diharapkan dapat menelaah struktur, isi, dan kebahasaan teks eksposisi. pada proses pembelajaran, guru dapat mengambil contoh artikel dalam penelitian ini beserta pembahasannya. Siswa diharapkan dapat menelaah struktur, isi, dan kebahasaan artikel tersebut. Selain itu, siswa juga diharapkan memahami analisis kesalahan ejaan pada artikel tersebut sehingga siswa dapat belajar dari kesalahan-kesalahan ejaan yang disajikan serta dapat mengaplikasikan pemahamannya pada penulisan artikel atau teks eksposisi. Oleh karena itu, penelitian ini dapat dijadikan referensi atau rujukan dalam pembelajaran bahasa Indonesia, khususnya materi teks eksposisi.

\section{DAFTAR PUSTAKA}

Afiana, Nur. 2018. "Analisis Kesalahan Berbahasa Indonesia Tataran Kadera Bahasa, Volume 12 Nomor 2, Edisi Agustus 2020

Ejaan dalam Karangan Siswa." Konferensi Ilmiah Dasar, 1:68-78.

Afifuddin dan Saebani, Bani A. 2012. Metodologi Penelitian Kualitatif. Bandung: CV. Pustaka Setia.

Fathan. 2014. Pengantar Jurnalistik. Surakarta: EFUDE PRESS.

Gantamitreka dan Shokha. 2016. Kesalahan Berbahasa Penggunaan EYD (Ejaan Yang Disempurnakan). Solo: Genta Smart Publisher.

Inderasari, E. dan Agustina, T. 2017. "Pembelajaran Bahasa Indonesia pada Mahasiswa Asing dalam Program BIPA IAIN Surakarta." Jurnal Pendidikan Bahasa dan Sastra Indonesia, 6(2). 6-15.

Kemendikbud. 2016. Pedoman Umum Ejaan Bahasa Indonesia. Jakarta: Kemendikbud.

Muhammad. 2014. Metode Penelitian Bahasa. Yogyakarta: Ar-Ruzz Media.

Murni, Diana. 2017. "Analisis Kesalahan Penggunaan Kalimat Bahasa Indonesia dalam Penulisan Tajuk di Surat Kabar Banjarmasin Post (The Error Analysis of The Using of Indonesian Language Sentences in The Writing of 
Editorials on Banjarmasin Post" Jurnal Bahasa, Wachidah, M., Oktavy, N. R. dan Sari, M. I. 2019. Sastra dan Pembelajarannya, 7(2): 301-309.

Rosita, F.Y. dan Achsani, F. 2018. "Ketidakefektifan Kalimat dalam Karangan Liburan Siswa Kelas X SMK IPTEK Weru." WACANA: Jurnal Bahasa, Seni, dan Pengajaran, 2(2):21-32.

Sarwoko, T.A. 2007. Inilah Bahasa Indonesia Jurnalistik. Yogyakarta: CV. Andi Offset.

Setyawati, Nanik. 2010. Analisis Kesalahan Berbahasa Indonesia: Teori dan Praktik. Surakarta: Yuma Pustaka.

Tarigan. 2011. Pengajaran Analisis Kesalaban Berbahasa. Bandung: Angkasa.

Tamburaka, Apriadi. 2013. Literasi Media: Cerdas Bermedia Khalayak Media Massa. Jakarta: PT RajaGrafindo Persada. "Analisis Kesalahan Berbahasa dalam Brosur PPDB (Penerimaan Peserta Didik Baru) SMA Sederajat Kabupaten Boyolali" Jurnal Edukasi Khatulistiwa Pembelajaran Bahasa dan Sastra, 2(2): 1-7.

Wijana, Putu. 2011. Berkenalan dengan Linguistik. Yogyakarta: A.com Press.

Wijayanti, A. 2016. "Analisis Kesalahan Penggunaan Ejaan pada Skripsi Mahasiswa Program Studi di Pendidikan Guru Sekolah Dasar Fakultas Keguruan dan Ilmu Pendidikan Universitas Darul Ulum Islamic Centre Sudirman GUPPI UNDARIS" Media Penelitian Pendidikan, 10 (2):184-198.

Yunus, Syarifudin. 2010. Jurnalistik Terapan. Bogor: Ghalia Indonesia. 